\title{
RISK ZONING IN THE CONTEXT OF INSURANCE: COMPARISON OF FLOOD, SNOW LOAD, WINDSTORM AND HAILSTORM
}

\author{
Dr Tomas Hanak* \\ Faculty of Civil Engineering, Brno, Czech Republic \\ Jana Korytarova, \\ Faculty of Civil Engineering, Brno, Czech Republic
}

Natural disasters may have a catastrophic impact on the lives of people, company operations and property. The impacts of these disasters fall into the category of natural hazards and belong to standard insurance policies; however, they are problematic from the point of view of the varying degree of risk facing the insured objects in different locations. The objective of this paper is to discuss and assess the potential of applying risks zoning to the Czech Republic on the examples of the selected natural hazards of floods, snow load, windstorm and hailstorm. The assessment is conducted using available statistical data and a severity index. It is concluded that after the flood hazard, it is the combined risk of windstorm and hailstorm which has the biggest potential for the introduction of risk zoning for insurance purposes.

Key words: Flood, Insurance, Risk, Snow load, Windstorm, Zone

\section{INTRODUCTION}

The adverse impact of natural phenomena represents a significant threat to both private and public property as well as the lives and health of individuals. Natural disasters of an extreme scale bring about enormous damage to both personal and real property; especially significant is the damage or destruction of residential buildings, production facilities or technical and transport infrastructure. From the perspective of the insurance companies, the adjustment of claims arising from natural disasters noticeably disturbs their financial balance, as the insurance benefit claims are often markedly higher in the short term than the volume of paid premiums. At the same time, there is a lack of claim adjusters, as the insurance companies have to resolve a large number of loss events in a very short period. From this perspective, it seems desirable to discuss the introduction of risk zones, which would take into account the extent of the specific natural hazard in a given locality and thus justify the need for a higher premium in those areas where the risk is realised more often and where the insurance benefits must be therefore also paid more often.

The objective of this paper is to discuss and assess the potential of applying risks zoning to the

\footnotetext{
${ }^{*}$ Faculty of Civil Engineering, Antonínská 548/1, 60190 Brno
}

Czech Republic; hanak.t@fce.vutbr.cz
Czech Republic on the examples of the selected natural hazards of floods, snow load, windstorm and hailstorm in the context of property insurance. This paper does not attempt to suggest or assess the parameters of specific risk zoning set-ups; its aim is to highlight the importance of risk zoning for the insurance market and also the related differences between selected insurable natural hazards.

The paper is structured in the following way: The first part introduces risk zoning in relation to insurance. Afterwards, the significant natural hazards in the Czech Republic are presented, including available statistical data (the extent and number of losses). The selected hazards are then assessed and prioritized on the basis of the ascertained data and a severity index. The final part discusses the potential of risk zoning application in relation to the basic parameters of a given hazard and other related influencing factors; the research limitations of this study are also mentioned.

\section{RISK ZONING AND ITS APPLICATION FOR INSURANCE PURPOSES}

Insurance is based on solidarity, with the policyholders contributing premiums to the insurance fund so as to gather sufficient funds to cover possible future losses (that is, the amount 
of paid insurance benefits). The extent of future losses may be estimated e.g. from historical data based on the probability that a certain event will occur and on the expected severity of its impact in a specific region and period of time. However, there is the problem of low probability and high loss events, which can be defined as risky situations where the probability of occurrence is low, but the harmful effect may be very significant (as in the case of natural disasters) [17]. More frequent losses resulting from disasters then necessarily lead to thoughts about the introduction of risk zones, which allow the level of risk in a given location to be taken into account. Fell et al., 2008, define the concept of zoning in the context of the landslide hazard as the division of land into homogeneous areas or domains and their ranking according to the degree of actual or potential landslide susceptibility, hazard or risk or the applicability of certain hazard-related regulations [07]. In a more general view, risk zoning represents an assessment of a potential damage to the elements facing the risk in relation to vulnerability and temporal and spatial probability. Risk zones may be created for various natural hazards, such as earthquake [01], [27], flood [03], wind [08], hurricane [21], landslide [06], [20], debris flow [04] or tsunami [23], but also for other purposes, such as managing the integrated environmental risks and ensuring their optimal spatial distribution in a populated area [28].

The prospect for risk zoning in the field of insurance is to introduce a variable premium with regard to the respective risk zone categorisation of the insured property and also to prevent the insurance of property in the zone with the highest degree of risk. This is because such objects do not meet all the criteria of insurability, namely the criterion of random occurrence, as the risk occurs repeatedly, that is, with certain regularity. In Germany, for example, buildings in the highrisk zone, where flooding occurs on average at least once in 10 years, are generally not insurable [25]. The insurability criteria in the context of large losses are described in the study by Berliner [02].

\section{RISKS AND NATURAL DISASTERS IN THE CZECH REPUBLIC}

Since 1980 , more than 26,000 natural disasters have been recorded worldwide [10]. They are mostly connected to earthquakes, tsunami, volcanic eruptions, storms, floods and high temperatures resulting in wildfires etc. Within the natural perils classification, 4 peril families can be established: geophysical (earthquakes, volcanic eruptions, mass movement dry), meteorological (i.e. storms in general, including for example hailstorms, dust storms or tornadoes), hydrological (floods, avalanches or landslides) and climatological (extreme temperatures, droughts or wildfires) [10]. In the Czech Republic, the hydrological and the meteorological families are among the most important ones; floods (e.g. 1997 Morava and Odra rivers, 2002 VItava and Labe rivers) and windstorms (e.g. 2007 Kyrill, 2008 Emma) may be named among the recent examples. The Czech Insurance Association statistics of losses arising from natural disasters are also compiled in this context [05]: they distinguish three main types of hazards, namely 1 . snow load, 2 . floods and 3 . the aggregate hazards of windstorms and hailstorms. A list of losses arising from other hazards is not available. Therefore, on the basis of available data, the paper assesses the hazard of snow load, the hazard of flood and also the hazard of wind- and hailstorm as one aggregate hazard.

To assess the individual hazards from the point of view of the insurance companies, it is important to follow the total number of individual losses in time as well their aggregate amount expressed in monetary units. The above mentioned data allows the comparison of individual hazards from the point of view of their significance and the frequency of their occurrence, also in the context of a catastrophic extent. In actuarial terms, specific aggregate yearly indicators can also be analysed, such as the loss ratio (ratio between the insurance benefit and the premium) or loss frequency (how often losses occur). It is vital for the insurance companies that the value of the paid insurance benefit is lower than the collected premium in the long term. Data on the amount of losses and the number of insured events in 2006-2013 for the selected hazards of snow load, flood and wind- and hailstorm is shown in Table 1 and Table 2 respectively (note: the aggregate yearly data for 2008 is not available). 
Table 1: Value of Annual Losses During 2006-2013 (in thousands of CZK); source: [05]

\begin{tabular}{|l|c|c|c|c|c|c|c|}
\hline Year & 2006 & 2007 & 2009 & 2010 & 2011 & 2012 & 2013 \\
\hline Total & $4,590,946$ & $3,542,061$ & $3,755,428$ & $7,914,049$ & $1,625,324$ & $2,242,200$ & $9,315,909$ \\
\hline Snow Load & $2,564,492$ & 20,603 & 309,790 & $1,212,759$ & 264,944 & 148,399 & 124,402 \\
\hline Flood & $1,340,848$ & 386,892 & $1,508,902$ & $3,994,437$ & 326,850 & 353,794 & $7,457,780$ \\
\hline Wind- and Hailstorm & 685,606 & $3,134,566$ & $1,936,736$ & $2,706,853$ & $1,033,530$ & $1,740,007$ & $1,733,727$ \\
\hline
\end{tabular}

Table 2: No. of Insured Events During 2006-2013; source: [05]

\begin{tabular}{|l|c|c|c|c|c|c|c|}
\hline Year & 2006 & 2007 & 2009 & 2010 & 2011 & 2012 & 2013 \\
\hline Total & 117,942 & 121,822 & 77,568 & 145,881 & 43,332 & 52,016 & 92,185 \\
\hline Snow Load & 68,690 & 1,677 & 17,183 & 55,417 & 11,622 & 8,250 & 7,744 \\
\hline Flood & 31,262 & 12,121 & 25,010 & 38,367 & 10,107 & 9,938 & 47,041 \\
\hline Wind- and Hailstorm & 17,990 & 108,024 & 35,375 & 52,097 & 21,603 & 33,828 & 37,400 \\
\hline
\end{tabular}

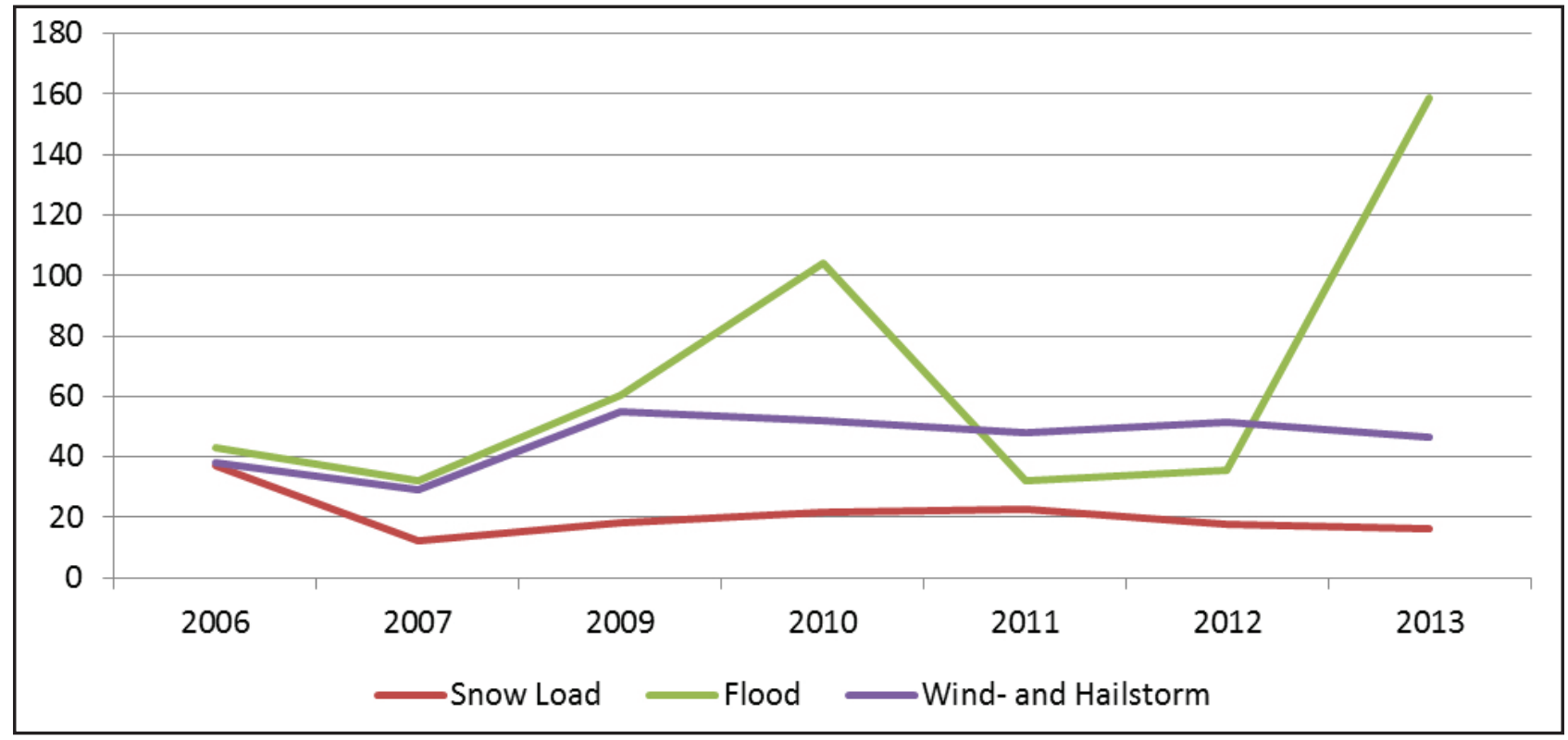

Figure 1: Average Loss During 2006-2013 (in thousands of CZK per insured event); created according to [05]

In the examined period between 2006 and 2013, there is a clear prevalence of loss events caused by windstorms $(343,333$ events). On the other hand, the amount of losses cause by other examined natural phenomena is comparable $(170,790$ events for snow load and 174,104 events for floods). In this context, the most significant risk seems to be windstorm/hailstorm. However, it is also necessary to consider the extent of the individual losses. The comparison of the extent of losses caused by the individual natural phenomena (Table 1) and the amount of an average loss (Figure 1) shows that the amount of an average loss related to the flood hazard increases significantly in case of extraordinary events (see years 2010 and 2013), while a similar dependency cannot be found in the other two natural phenomena (snow load and wind- and hailstorm). In
2007 (the Kyrill hurricane), the highest number of loss events was recorded; however, the average loss for the hazard of wind- and hailstorm was surprisingly low. For both snow load and windand hailstorm it also holds that in the examined period, the absolute fluctuations of the amount of the average loss are not significant.

\section{THE CURRENT SITUATION AND T HE PROSPECTS OF RISK ZONING IN THE CZECH REPUBLIC}

To assess the prioritization of risks, it is necessary to take into account also the significance of the deviations of extreme events for the individual hazards. Even when there is an extreme event (expresses by a high number of insured events) related to a specific hazard, the caused losses may not necessarily represent critical damage 
to property; that is, the realisation of the hazard causes numerous, but only partial damage to property. On the contrary, for some hazards it may be presumed that in case of an extreme event, the damage to property will be critical (total loss). For example, in case of an extreme earthquake or flood, it is probable that the damage to the structure of a building will be such that it will be no longer possible to use it. On the other hand, in the case of an extreme realisation of the windstorm or snow load hazard, it is probable that a building will only be damaged partially and only partial repairs will be necessary (such as repairs of the roof structure and windows).

For these purposes, an index of the severity of the extreme event impact (SI - severity index) can be created. The index expresses the ratio of the average loss amount for a specific ith hazard in a given year (PAL - partial average loss) and the overall average loss amount for all the hazards over the whole examined period (OAL - overall average loss).

$S I_{i}=\frac{\mathrm{PAL}_{i}}{\mathrm{OAL}}$

If the value of as $S I<1$, the severity of the event in case of natural disaster realisation is low; if the value is close to 1 , the severity is average, and if the value of $\mathrm{SI}>1$, the severity of the event is high. In general, the higher the SI value, the higher the severity of the disaster event. The SI values for the examined period are shown in Table 3.

Table 3: SI (Severity Index) Values

\begin{tabular}{|l||c|c|c|c|c|c|c|c|}
\hline Year & 2006 & 2007 & 2009 & 2010 & 2011 & 2012 & 2013 & MAX \\
\hline Snow Load & 0.75 & 0.25 & 0.36 & 0.44 & 0.46 & 0.36 & 0.32 & 0.75 \\
\hline Flood & 0.86 & 0.64 & 1.21 & 2.09 & 0.65 & 0.72 & 3.19 & 3.19 \\
\hline Wind- and Hailstorm & 0.77 & 0.58 & 1.10 & 1.04 & 0.96 & 1.03 & 0.93 & 1.10 \\
\hline
\end{tabular}

Note: due to the unavailability of yearly data, 2008 is not assessed.

Given the statistical data (Table 1 and Figure 1) and the reached SI values (Table 3), the following order can be assigned to the individual hazards with regard to their prioritisation in the context of risk zone introduction potential - see Table 4.

\section{Table 4: Prioritization of Selected Hazards}

\begin{tabular}{|c|l|l|}
\hline Order & Hazard & Reasons \\
\hline $1^{\text {st }}$ & Flood & $\begin{array}{l}\text { Occurrence of an extreme event; the average loss amount increases } \\
\text { significantly in case of a large-extent event. Max SI = 3.19. }\end{array}$ \\
\hline \hline $2^{\text {nd }}$ & Windstorm and Hailstorm & $\begin{array}{l}\text { Occurrence of an extreme event; the average loss amount does not } \\
\text { increase significantly in case of a large-extent event. Max SI }=1.10 .\end{array}$ \\
\hline \hline $3^{\text {rd }}$ & Snow Load & $\begin{array}{l}\text { Occurrence of an extreme event; the average loss amount does not } \\
\text { increase significantly in case of a large-extent event. Max SI }=0.75 .\end{array}$ \\
\hline
\end{tabular}

The insurance companies currently apply risk zoning to the flood hazard in reaction to the losses caused by the floods in the years 1997 and 2002 (see Table 5). The results of hazard prioritisation shown in Table 4 support this practice. The flood maps distinguish 4 flood zones; the level of danger for a given locality can be found online [19]. The statistical data also shows that the ratio of individual flood zones in individual re- gions varies; in the Olomouc and Zlín Regions, for example, the ratio of the third zone is more than $10 \%$ [24]. Similar differences can be found for other natural phenomena as well, e.g. according to the statistics of the main natural disaster events for 2013 (valid for both windstorm and hailstorm and also for snow load) [5]. For this reason, wind- and hailstorm seems to be a justified candidate for the introduction of risk zoning.

Table 5: Basic Flood Data from 1997 and 2002 [05]

\begin{tabular}{|c|c|c|c|}
\hline Year & No. of Insured Events & Overall Losses (both Insured and Uninsured) & Fatalities \\
\hline 1997 & 117,000 & CZK 62 billion & 60 \\
\hline 2002 & 81,000 & CZK 73 billion & 17 \\
\hline
\end{tabular}


A correct setting of the risk zones requires the use of an appropriate methodology. The methodology of risk area zoning and assessment presented in [26], which use the so-called "risk factor" (RF), computed as a product of the hazard factor and the vulnerability factor, is an example of such methodology. In another study, the "risk score" is determined as the aggregate weighted sum of each of the loss measures in each of the different sectors (impact on people, economy, environment, infrastructure and intangible property) [12].

It is also possible to modify the current flood methodology used in the Czech Republic with regard to the characteristics of a specific hazard and the typically affected construction (see Table 6 ), the expected extent of the losses that can be estimated on the basis of loss curves [13] and the frequency of the occurrence of the event in specific locations.

Table 6: Characteristics of Selected Hazards and Damage; created according to [09], [15]

\begin{tabular}{|c||c|c|}
\hline Hazard & Fragility Variable & Performance Limit States, Typical Loss \\
\hline Snow Load & $\begin{array}{c}\text { Height of snow cover (snow load) } \\
{[\mathrm{kg} / \mathrm{m} 2]}\end{array}$ & $\begin{array}{c}\text { Exceeding the roof system capacity, dam- } \\
\text { age of roof structure }\end{array}$ \\
\hline Flood & $\begin{array}{c}\text { Depth of water [m], duration [days], } \\
\text { velocity [m/s] }\end{array}$ & $\begin{array}{c}\text { Percentage of replacement value; plaster, } \\
\text { flooring, painting, moisture in structures }\end{array}$ \\
\hline Wind- and Hailstorm & Gust speed [m/s] & $\begin{array}{c}\text { Roof removal, window loss, roof to wall } \\
\text { connection failure }\end{array}$ \\
\hline
\end{tabular}

The level of detail in the division of risk zones is also to be considered. Both scientific studies and practice show (see Table 7) that the number of risk zones for different risks is not uniform; it is usually between 3 and 7 . For the purposes of dividing an area into risk zones so as to set an adequate level of premium, 4 zones seem to be sufficient (as the current system of flood zones shows); the number of zones could be possible increased to 5 (Table 7).

Table 7: Number of Risk Zones for Selected Hazards Used in Scientific Studies and in Practice

\begin{tabular}{|l|c|c|c|c|c||}
\hline No. of Zones & 3 & 4 & 5 & 6 & 7 \\
\hline Flood & {$[22]$} & {$[18],[19],[30]$} & {$[11],[26]$} & & \\
\hline Wind, Hurricane & & {$[21]$} & & & [8] \\
\hline Landslide & {$[20]$} & & {$[6],[29]$} & & \\
\hline Debris Flow & {$[4]$} & & & & \\
\hline Environmental Risks & & {$[28]$} & & & \\
\hline Tsunami & & {$[23]$} & & & \\
\hline Earthquake & & {$[1],[27]$} & {$[16]$} & & {$[16]$} \\
\hline Hailstorm & & & & & \\
\hline
\end{tabular}

The suitability of a hazard for zoning is also influenced by other parameters, such as the existence of hazard mapping and GIS support. Using GIS allows for example to model the depth of water in case a specific scenario of a flood occurs in the area [14], which is a significant factor influencing the level of risk and the extent of the possible future loss in urban areas. A clear summary of the key influences identified and discussed in this study in relation to their impact on the application of risk zoning is given in Figure 2.

\section{RESEARCH LIMITATIONS}

The results presented in this study have the following limitations. First, it must be noted that the analysis and the discussion in the study only concerns years 2006 to 2013 (as older data is not available). For more relevant results, a data set for a longer period of time would be necessary - an optimum period would be 100 years or more, as e.g. in case of floods the level of the socalled 100-year flood is assessed. The authors point out the fact that the data does not include two extreme floods in 1997 and 2002 (see Table 
5), which are remarkably extraordinary in both their extent and their impact. The inclusion of these floods into the calculations would probably bring about an even higher rating of the flood hazard as regards the SI value.

Second, it must be mentioned that the statistical values taken from [05] are total losses and numbers of insured events without any detailed division. Further results and a more detailed discussion could be achieved in case the aggre- gate values were divided and categorised into individual insurance products (such as building insurance, household insurance, motor vehicle insurance). Third, because of the structure of the available statistical data, the windstorm and hailstorm hazards are assessed together in this research. The authors are aware that if it were possible to examine these two natural phenomena individually, the results could prove other correlations as well.

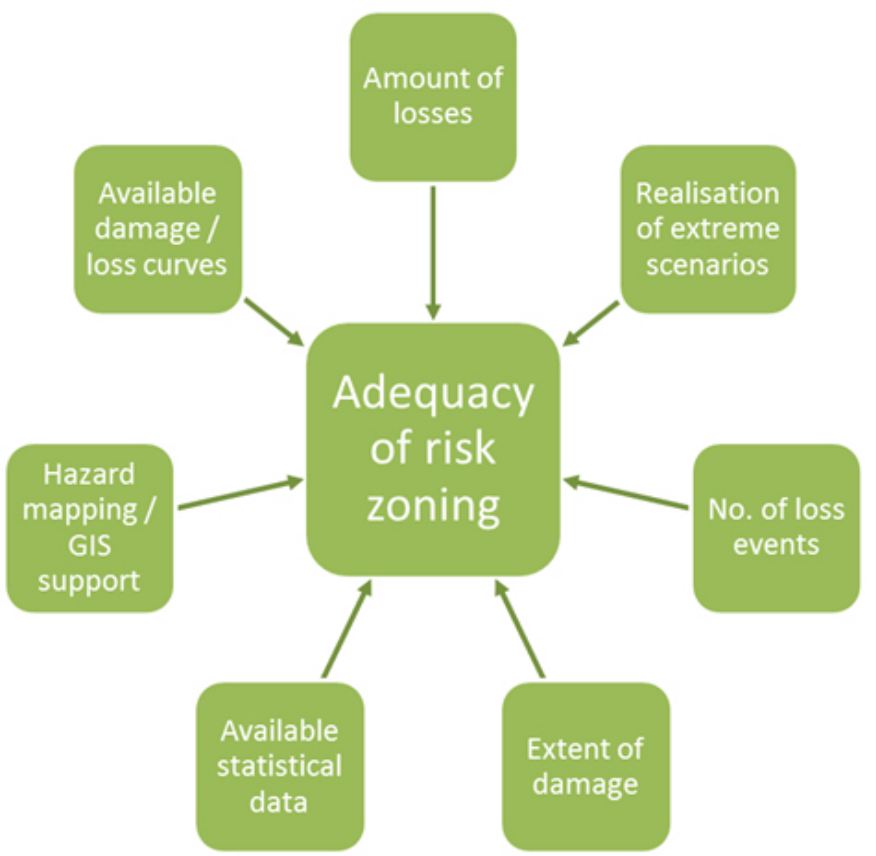

Figure 2: Parameters Influencing the Suitability and Readiness of a Hazard for Zoning

\section{CONCLUSION}

For the insurance companies, the least favourable situation in case of a natural disaster is the realisation of a hazard against which a high proportion of the market is insured. Introducing risk zoning for other risks in a similar way as in the case of floods would allow a fairer distribution of the contribution for the reimbursement of future losses among the policyholders and an increase of the volume of the insurance fund to cover future losses caused by natural disasters. From the hazards examined in this paper in the given period, wind- and hailstorms seem to be good candidates for the introduction of risk zoning, especially as they have the highest number of recorded insured events, significant values of total losses comparable to the flood hazard and acceptable SI values.

The financial stability of the insurance companies and their ability to pay the insurance ben- efits without delay is a basic prerequisite for a quick recovery of the affected area (repairs or construction of residential buildings and technical infrastructure) and a revival of the economic activity of business entities. The introduction of risk zones becomes an important aspect not only for the above mentioned reason, but also in relation to the increasing frequency of the occurrence of natural disasters related to the global climate change; therefore, this will remain an important area for the insurance companies in the future.

Future research should be directed towards a more detailed comparison of more types of hazards with regard to their significance for the financial results of the insurance companies. This presumes the securing of more detailed statistical data on the part of the insurer (a more detailed division according to insurance products, locations or types of damaged property, adding more hazards into the database etc.). Another 
interesting area for further research could be the reflection of the technical parameters of the buildings (such as the resistance of the roof covering to windstorms and hailstorms) in the premium rate.

\section{ACKNOWLEDGMENTS}

Brno University of Technology, Faculty of Civil engineering; Project number: FAST-S-14-2488; Project title: Effective management of processes in construction.

\section{REFERENCES}

1) Anthmos, A., Marius, M. (2010): Vulnerability assessment of $\mathrm{R} / \mathrm{C}$ buildings for earthquake insurance purposes, Proceedings of the International Conference on Risk Management, Assessment and Mitigation, RIMA '10 2010, pp. 126-131.

2) Berliner, B. (1985): Large risks and limits of insurability. The Geneva Papers on Risk and Insurance, Vol. 10, No. 37, pp. 313-329.

3) Bin, O., Kruse, J.B., Landry, C.E. (2008): Flood hazards, insurance rates, and amenities: Evidence from the coastal housing market. Journal of Risk and Insurance, Vol. 75, No. 1, pp. 63-82.

4) Cui, P., Zou, Q., Xiang, L., Zeng, C. (2013): Risk assessment of simultaneous debris flows in mountain townships. Progress in Physical Geography, Vol. 37, No. 4, pp. 516542.

5) Czech Insurance Association, official web page. http://www.cap.cz, retrieved on April 10th, 2014

6) Demir, G., Aytekin, M., Akgün, A., Ikizler, S.B., Tatar, O. (2013): A comparison of landslide susceptibility mapping of the eastern part of the North Anatolian Fault Zone (Turkey) by likelihood-frequency ratio and analytic hierarchy process methods. Natural Hazards, Vo. 65, No. 3, pp. 1481-1506.

7) Fell, R., Corominas, J., Bonnard, C., Cascini, L., Leroi, E., Savage, W.Z. (2008): Guidelines for landslide susceptibility, hazard and risk zoning for land-use planning. Engineering Geology, Vol. 102, No. 3-4, pp. 99-111.

8) Goliger, A.M., Retief, J.V. (2002): Identification of zones of strong wind events in South Africa. Journal of Wind Engineering and Industrial Aerodynamics, Vol. 90, No. 11, pp. 1227-1235.
9) Hanak, T.: Procedia Social and Behavioral Sciences,

10) Hoeppe, P. (2009): Munich re tools for standardised Nat Cat data collection and hazard mapping. In Conference on the Financial Management of Large-Scale Catastrophes. Ppt presentation, $32 \mathrm{p}$.

11) Jiang, W., Deng, L., Chen, L., Wu, J., Li, J. (2009): Risk assessment and validation of flood disaster based on fuzzy mathematics. Progress in Natural Science, Vol. 19, No. 10, pp. 1419-1425.

12) Komendantova, N., Mrzyglocki, R., Mignan, A., Khazai, B., Wenzel, F., Patt, A., Fleming, K. (2014). Multi-hazard and multi-risk decision-support tools as a part of participatory risk governance: Feedback from civil protection stakeholders. International Journal of Disaster Risk Reduction, Vol. 8, pp. 50-67.

13) Korytarova, J.: Agricultural Economics

14) Kulkarni, A.T., Mohanty, J., Eldho, T.I., Rao, E.P., Mohan, B.K. (2014): A web GIS based integrated flood assessment modelling tool for coastal urban watersheds. Computers and Geosciences, Vol. 64, pp. 7-14.

15) Li, Y., van de Lindt, J.W. (2012): Loss-based formulation for multiple hazards with application to residential buildings, Engineering Structures, Vol. 38, pp. 123-133.

16) Munich Re. (2011): NATHAN world map of natural hazards. 7 p. http://www.munichre.com/site/corporate/get/documents/ $\mathrm{mr} /$ assetpool.shared/Documents/0 Corporate\%20Website/_Publications/30205972_en.pdf, retrieved on April 5th, 2014

17) Ozdemir, O., Morone, A. (2014): An experimental investigation of insurance decisions in low probability and high loss risk situations. Journal of Economic Interaction and Coordination, Vol. 9, No. 1, pp. 53-67.

18) Pompe, J.J., Rinehart, J.R. (2008): Property insurance for coastal residents: Governments' "III Wind". Independent Review, Vol. 13, No. 2, pp. 189-207.

19) Intermap Technologies, s.r.o. (2010): Průvodce pro zjištění nebezpečí výskytu povodně. https://riskportal.intermap.cz/ , retrieved on April 2nd, 2014.

20) Rahman, A., Khan, A.N., Collins, A.E. (2014): Analysis of landslide causes and associated damages in the Kashmir Himalayas of Paki- 
stan. Natural Hazards, Vol. 71 , No. 1, pp. 803-821.

21) Stanturf, J.A., Goodrick, S.L., Outcalt, K.W. (2007): Disturbance and coastal forests: A strategic approach to forest management in hurricane impact zones. Forest Ecology and Management, Vol. 250, No. 1-2, pp. 119-135.

22) Štěpánková, P., Drbal, K. (2008): Flood risk maps in the Czech Republic. In XXIVth conference of the Danubian countries on the hydrological forecasting and hydrological bases of water management. 7 p., http://ksh.fgg. uni-lj.si/bled2008/cd_2008/02_Hydro-meteo rological $\% 20$ extremes, $\% 20$ floods $\% 20$ and $\%$ 20droughts/090_Stepankova.pdf, retrieved on 12.4.2014

23) Sumarjono, J. (2009): Hazard mapping, Risk Assessment, and Insurance Coverage of Natural Catastrophe Risk. In Conference on the Financial Management of Large-Scale Catastrophes. 16 p. http://www.oecd.org/finance/insurance/43684066.pdf , retrieved on 12.4 .2014

24) Svačina, L. (2009): Dosáhne povodeň až k vašemu domu? http://www.hypoindex.cz/ dosahne-povoden-az-k-vasemu-domu/ , retrieved on 8.4.2014
25) Thieken, A.H., Petrow, T., Kreibich, H., Merz, B. (2006): Insurability and mitigation of flood losses in private households in Germany. Risk Analysis, Vol. 26, No. 2, pp. 383-395.

26) Tingsanchali, T. Karim, F. (2010): Flood-hazard assessment and risk-based zoning of a tropical flood plain: Case study of the Yom River, Thailand. Hydrological Sciences Journal, Vol. 55, No. 2, pp. 145-161.

27) Verma, M., Bansal, B.K. (2013): Seismic hazard assessment and mitigation in India: An overview. International Journal of Earth Sciences, Vol. 102, No. 5, pp. 1203-1218.

28) Yang, Y., Ma, J. (2010): Study on risk zoning technology of major environmental risk sources in Urban scale and its application in Shanghai, China, Procedia Environmental Sciences, Vol. 2, pp. 1050-1062.

29) Yhang, W., Wang, W., Xia, K. (2012): Landslide Risk Zoning Based on Contribution Rate Weight Stack Method. Energy Procedia, Vol. 16, pp. 178-183.

30) Zeleňáková, M. (2011): Flood risk assessment and management in Slovakia. WIT Transactions on Ecology and the Environment, Vol. 146, pp. 61-70.

Paper sent to revision: 14.03.2014.

Paper ready for publication: 10.06.2014. 